\title{
RESEARCH PAPER \\ Physiological characterization of two native yeasts in pure and mixed culture using fermentations of agave juice
}

\author{
Martha E. Nuñez-Guerrero ${ }^{1,2}$, Elizabeth Salazar-Vázquez², Jesús B. Páez- \\ Lerma $^{2}$, Raúl Rodríguez-Herrera ${ }^{1}$, and Nicolás O. Soto-Cruz ${ }^{2}$ \\ ${ }^{1}$ Universidad Autónoma de Coahuila, Faculty of Chemical Sciences, Laboratory of Molecular Biology. Blvd. \\ V. Carranza e Ing. José Cardenas s/n, Saltillo Coahuila, México. \\ ${ }^{2}$ Tecnológico Nacional de México/Instituto Tecnológico de Durango. Felipe Pescador 1830 Ote. 34080, \\ Durango, Dgo., México.
}

\begin{abstract}
M.E. Nuñez-Guerrero, E. Salazar-Vázquez, J.B. Páez-Lerma, R. Rodríguez-Herrera, and N.O. Soto-Cruz. 2019. Physiological characterization of two native yeasts in pure and mixed culture using fermentations of agave juice. Cien. Inv. Agr. 46(1): 1-11. Yeast cells are subjected to diverse environmental conditions during the alcoholic fermentation of agave juice, causing different kinetic behaviors. Agave juice was used as culture medium to evaluate the kinetic behavior of Saccharomyces cerevisiae ITD-00185 and Torulaspora delbrueckii ITD$00014 \mathrm{a}$, as pure and mixed cultures, under different inoculum sizes $\left(1 \times 10^{5}, 1 \times 10^{6}, 1 \times 10^{7}\right.$ and $1 \times 10^{8}$ cells mL $\left.\mathrm{mL}^{-1}\right)$, and combined $\mathrm{pH}$ levels $(3.5,4.0$ and 4.5$)$ and temperatures $\left(18^{\circ} \mathrm{C}, 28^{\circ} \mathrm{C}\right.$ and $38{ }^{\circ} \mathrm{C}$ ). Saccharomyces cerevisiae displayed high fermentation capacities at all inoculum concentrations assayed. However, $T$. delbrueckii required a high inoculum concentration $\left(\geq 1 \times 10^{7}\right.$ cells $\left.\mathrm{mL}^{-1}\right)$ to perform at fermentation levels similar to $S$. cerevisiae. Low temperatures $\left(18^{\circ} \mathrm{C}\right)$ slowed fermentation, while high temperatures $\left(38^{\circ} \mathrm{C}\right)$ adversely affected the development of the yeast strains, especially $T$. delbrueckii. The best temperature was $28^{\circ} \mathrm{C}$ in all fermentations. The $\mathrm{pH}$ level had a strong effect on the performance of the coculture, since the fermentation kinetics suggested a synergistic effect at $\mathrm{pH} 4.5$, while an antagonistic effect was postulated at $\mathrm{pH}$ 3.5. In all of the mixed culture cases, a positive effect at $28^{\circ} \mathrm{C}$, especially at $\mathrm{pH} 4.0$ and 4.5 , was demonstrated by greater levels of sugar consumption and ethanol production ( $\sim 20 \%$, $\mathrm{p}<0.05$ ) compared to fermentations of the $S$. cerevisiae monoculture. The coculture results allow us to postulate that a complex interaction exists between the two yeasts, which could be synergistic or antagonistic, as the environmental conditions change.
\end{abstract}

Key-words: Coculture, inoculum concentration, $\mathrm{pH}$, Temperature.

\section{Introduction}

Several different alcoholic beverages are derived from agave plants such as pulque, tequila, bacanora and mezcal. However, only tequila, and more recently mezcal, have achieved interna-

Received Jul 26, 2018. Accepted Mar 04, 2019. Corresponding author: nsoto@itdurango.edu.mx tional recognition. Mezcal is a Mexican regional beverage with an origin denomination (Norma Oficial Mexicana: NOM-070.SCFI-1994). Tequila and mezcal are both protected under the North American Free Trade Agreement (NAFTA) and an "Agreement between the European Union and the United Mexican States on the mutual recognition and protection of designations for spirit drinks". 
Tequila is obtained by distilling fermented sugar from Agave tequilana, whereas mezcal is obtained from Agave duranguensis juice as well as other Agave species (Soto-García et al., 2009).

Fermentation is a critical stage for the quality and productivity of the mezcal production process. This stage is performed spontaneously during artisan processes, which can cause fermentation to occur over different lengths of time, the presence of undesirable products (e.g., methanol and furfural) and leave high amount of residual, nontransformed sugar. Saccharomyces and non-Saccharomyces yeasts are responsible for the alcoholic fermentation of agave juice (Escalante-Minakata et al., 2008; LappeOliveras et al., 2008; Narváez-Zapata et al., 2010; Páez-Lerma et al., 2013). Yeast population changes that occur during the alcoholic fermentation of $A$. duranguensis juice for mezcal production were studied by Páez-Lerma et al. (2013). They found that the early stage of the fermentation process was conducted by highly diverse yeast populations, which contained species such as Kluyveromyces marxianus, Torulaspora delbrueckii, Candida diversa, Pichia fermentans and Hanseniaspora uvarum; however, $S$. cerevisiae was the only yeast found at the end of the fermentation process. This finding is similar to the yeast behavior reported during grape fermentation for wine production (Esteve-Zarzoso et al., 1998; Pretorius et al. 2003; Caridi, 2003).

Standardizing the fermentation process could be achieved by using a starter culture (inoculant), formulated with selected yeast strains, which could possibly achieve better utilization of the fermentable sugars (Nuñez-Guerrero et al., 2016) while meeting the requirements of the Mexican Official Norm. Nuñez-Guerrero et al. (2016) demonstrated that a yeast mixture composed of $75 \%$ S. cerevisiae and $25 \%$ T. delbrueckii produced mezcal with a high yield and richness of volatile compounds, which resulted in better acceptability in sensory tests.

Therefore, the aim of this work was to evaluate the kinetic behavior of the abovementioned inoculant
(75\% S. cerevisiae and 25\% T. delbrueckii), as well as the individual yeasts, with reference to $\mathrm{pH}$, temperature and inoculum size, during the alcoholic fermentation of agave juice.

\section{Materials and Methods}

\section{Microorganisms}

Saccharomyces cerevisiae ITD-00185 and Torulaspora delbrueckii ITD-00014a strains were obtained from the yeasts collection of the Microbial Biotechnology Laboratory at the Instituto Tecnológico de Durango. These yeast strains were selected in a previous work (Nuñez-Guerrero et al., 2016) and were activated on Yeast-Peptone-Dextrose (YPD) agar (1\% yeast extract, $2 \%$ dextrose, $2 \%$ casein peptone, $2 \%$ agar), incubated at $28{ }^{\circ} \mathrm{C}$ for $12 \mathrm{~h}$ and recultured in YPD broth $(1 \%$ yeast extract, $2 \%$ dextrose, $2 \%$ casein peptone) at $28{ }^{\circ} \mathrm{C}$ for 12 $\mathrm{h}$. The cells were stained with methylene blue and counted using a Neubauer chamber.

\section{Agave juice}

Agave duranguensis juice with an initial sugar concentration of $120 \pm 5 \mathrm{~g} \mathrm{~L}^{-1}$ was kindly donated by Productora Mexicana de Mezcal S. DE R.L.M.I. Its total nitrogen was measured using the MicroKjeldahl method as described previously in De los Ríos-Deras et al., (2015). The agave broth had a nitrogen concentration of $0.49 \mathrm{~g} \mathrm{~N} \mathrm{~L}^{-1}$, and ammonium sulfate was added to reach $1.64 \mathrm{~g}$ $\mathrm{N} \mathrm{L}^{-1}$, which corresponds to a $\mathrm{C} / \mathrm{N}$ ratio of $73 \mathrm{~g}$ $\mathrm{C} / \mathrm{g}$ N. This $\mathrm{C} / \mathrm{N}$ ratio has been demonstrated as the best $\mathrm{C} / \mathrm{N}$ ratio for agave must fermentation during mezcal production (De los Ríos-Deras et al., 2015).

\section{Effect of inoculum concentrations}

Fermentation assays were performed using pure cultures of each yeast strain. A mixture culture 
(75\% S. cerevisiae and 25\% T. delbrueckii) was also used as inoculum as previously assayed in Nuñez-Guerrero et al., (2016). The measurements of the fermentation kinetics that were used to evaluate the inoculum concentration effect were performed in glass tubes $(20 \times 150 \mathrm{~mm})$, which were filled with $15 \mathrm{~mL}$ of agave juice and inoculated with either $1 \times 10^{5}, 1 \times 10^{6}, 1 \times 10^{7}$ and $1 \times 10^{8}$ cells $\mathrm{mL}^{-1}$ of agave culture in triplicate.

\section{Combined effect $\mathrm{pH}$-temperature}

A $3^{2}$ factorial design was performed to evaluate the effects of $\mathrm{pH}(3.5,4.0$ and 4.5) and temperature $\left(18^{\circ} \mathrm{C}, 28^{\circ} \mathrm{C}\right.$ and $\left.38^{\circ} \mathrm{C}\right)$. S. cerevisiae ITD-00185, T. delbrueckii ITD-00014a and the mixed culture (75\% S. cerevisiae and 25\% T. delbrueckii) were each assayed. Fermentation kinetics were performed in triplicate using agave juice at an initial sugar concentration of $120 \mathrm{~g} \mathrm{~L}^{-1}$ and a $\mathrm{C} / \mathrm{N}$ ratio of $73 \mathrm{~g}$ $\mathrm{C} / \mathrm{g} \mathrm{N}$ as the substrate. Fermentations were started using an inoculum of $10^{7}$ cells $\mathrm{mL}^{-1}$ and incubated at $28{ }^{\circ} \mathrm{C}$ for $72 \mathrm{~h}$. Samples were analyzed every $8 \mathrm{~h}$ by high-performance liquid chromatography as previously described by De los Ríos-Deras et al., (2015) to determine the glucose, fructose and ethanol concentrations.

\section{Statistical analysis}

The one-way ANOVA module of Statistica 7.0 (StatSoft Inc, USA) was used to check for significant differences among treatments using Fisher's test for least significant differences (LSD) among the means.

\section{Results and Discussion}

Nuñez-Guerrero et al. (2016) reported that a mixture of yeasts composed of $75 \%$ S. cerevisiae and $25 \%$ T. delbrueckii could potentially be used for the development of an inoculant for the production of mezcal and other related spirits. Nevertheless, it is necessary to establish the effect of the inoculum size and to perform some physiological studies before using the inoculant. This is because yeast cells can face environmental conditions during the alcoholic fermentation stage. Hohman and Mayer (2003) noted that yeasts typically face diverse conditions that primarily affect their cellular structures and different macromolecules, especially lipids, proteins and nucleic acids. Two of the most significant factors that may affect the yeasts' performance are the $\mathrm{pH}$ and the temperature (Viegas et al., 1989; Mauricio and Salmon, 1992; Alexandre et al., 1994a,b; Pampulha and Loureiro-Dias, 1990).

\section{Initial inoculum concentration}

Several fermentation kinetics were performed to determine the effects of the inoculum concentration (Fig. 1) to define the initial concentration of yeast cells that are required for the inoculant to promote efficient fermentation development. These experiments were performed for the mixed culture inoculant and for the separate yeast strains.

Figure 1A $\left(1 \times 10^{5}\right.$ cells $\left.\mathrm{mL}^{-1}\right)$ shows that $S$. cerevisiae displayed high fermentation levels at this inoculum concentration, consuming almost all of the sugars and producing $65 \mathrm{~g}$ ethanol $\mathrm{L}^{-1}$ by the end of the incubation time $(72 \mathrm{~h})$. A similar kinetic behavior was produced by the mixed yeast culture, reaching similar sugar consumption and ethanol production levels but in a slightly less time (66 h). Nevertheless, $T$. delbrueckii showed very a limited fermentation activity at this inoculum concentration, with only minor sugar consumption $\left(\sim 23 \mathrm{~g} \mathrm{~L}^{-1}\right)$ and limited ethanol production $\left(\sim 10 \mathrm{~g} \mathrm{~L}^{-1}\right)$. Similar findings are shown in Figure $1 \mathrm{~B}\left(1 \times 10^{6}\right.$ cells $\left.\mathrm{mL}^{-1}\right)$. S. cerevisiae and the mixed culture both performed very well and completely consuming the carbohydrates completely after 50-60 $\mathrm{h}$ of incubation; however, T. delbrueckii again showed a very limited fermentation capacity. The mixed culture showed slightly better kinetic 
behavior than the fermentation resulting from the inoculation of solely $S$. cerevisiae, which is a consistent finding for both inoculum concentrations $\left(1 \times 10^{5}\right.$ and $1 \times 10^{6}$ cells $\left.\mathrm{mL}^{-1}\right)$. This finding suggests a mechanism of collaboration or synergism between S. cerevisiae ITD-00185 and T. delbrueckii ITD-00014a at the proportions used in this work, as previously reported by our research group (Nuñez-Guerrero et al., 2016). In contrast, the poor performance of T. delbrueckii at these inoculum concentrations can be explained by chemical inhibition due to several compounds that are produced by the native microflora or low tolerance to osmotic stress, which have been suggested previously (Nishino et al., 1985; Hohmann, 2002). Another cause may be the inhibition of non-Saccharomyces yeasts by the native microflora of the agave juice or by cell-to-cell contact with $S$. cerevisiae, which has also been suggested previously (Nissen and Arneborg,
2003). Nevertheless, Taillandier et al. (2014) discarded cell-to-cell contact as well as substrate competition as the mechanisms inhibiting $T$. delbrueckii, instead suggesting inhibition by an $S$. cerevisiae-produced metabolite as the likely cause of these interactions.

Figure 1C shows the small difference between the kinetic performances at this inoculum concentration $\left(1 \times 10^{7}\right.$ cells $\left.\mathrm{mL}^{-1}\right)$ between the mixed culture and solely $S$. cerevisiae, with the mixed culture showing the best ethanol production. This figure also shows an improved kinetic behavior for T. delbrueckii in comparison to the previous inoculum sizes because it was able to consume almost all of the available sugars by the end of incubation period. Figure 1D shows virtually no differences between the kinetic performances of $S$. cerevisiae and T. delbrueckii inoculated separately or in a mixed culture at an inoculum concentration of $1 \times 10^{8}$ cells $\mathrm{mL}^{-1}$.
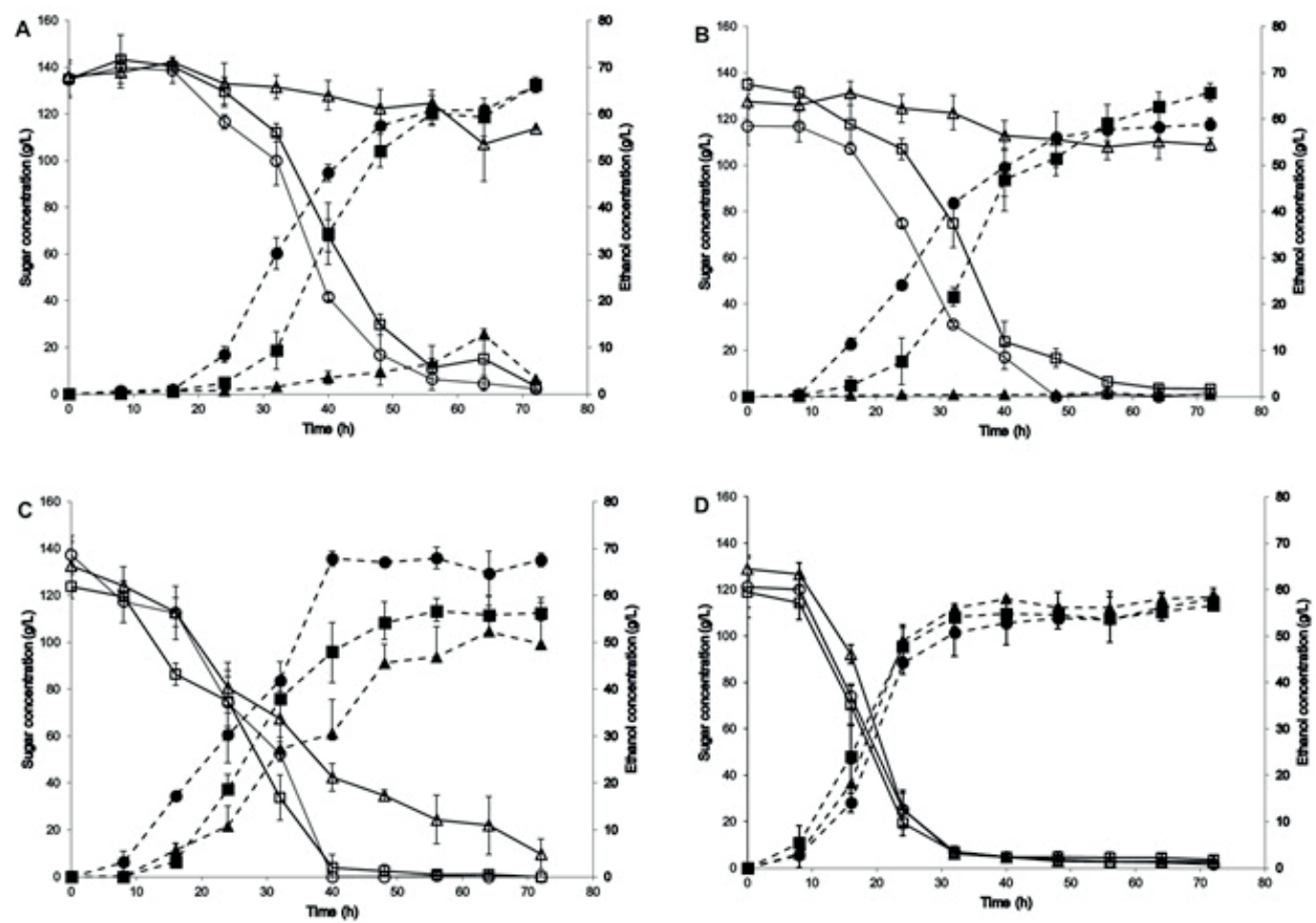

Figure 1. Fermentation kinetics in agave juice at different initial inoculum concentrations (cells $\left.\mathrm{mL}^{-1}\right)$. A) $1 \times 10^{5}$; B) $1 \times 10^{6}$; C) $1 \times 10^{7}$; D) $1 \times 10^{8}$. Sugar consumption by $S$. cerevisiae $(\square)$, T. delbrueckii $(\triangle)$ and mixed culture $(O)$. Ethanol production by $S$. cerevisiae $(\boldsymbol{\square})$, T. delbrueckii $(\boldsymbol{\Delta})$ and mixed culture ( $\bullet$ ). 
pH and temperature assays

Agave juice has a $\mathrm{pH}$ of approximately 4.0 and 28 ${ }^{\circ} \mathrm{C}$ is the average temperature in the agave producing regions during artisan mezcal production. The results obtained regarding the effects of $\mathrm{pH}$ and temperature using agave juice as the culture medium at an initial sugar concentration of $120 \mathrm{~g}$ $\mathrm{L}^{-1}$ are shown in Figures 2-4. Low temperatures $\left(18^{\circ} \mathrm{C}\right)$ slowed fermentation because $S$. cerevisiae required $40 \mathrm{~h}$ to reach the stationary phase for the kinetic studies performed at $\mathrm{pH} 4.0$ and 4.5, while the fermentation at $\mathrm{pH} 3.5$ required $60 \mathrm{~h}$ to reach the stationary phase (Fig. 2A). The ethanol production at this temperature (Fig. 2B) was approximately $31 \mathrm{~g} \mathrm{~L}^{-1}$ for every $\mathrm{pH}$ level tested. S. cerevisiae showed the best results at $28{ }^{\circ} \mathrm{C}$
(Fig. 2C and 2D), where it consumed sugars and produced ethanol in superior quantities at all of the $\mathrm{pH}$ levels tested. In contrast, the fermentation kinetics at $38^{\circ} \mathrm{C}$ (Fig. 2E and $2 \mathrm{~F}$ ) performed poorly, particularly at $\mathrm{pH} 3.5$. The sugar consumption reached approximately $65 \mathrm{~g} \mathrm{~L}^{-1}$ at $\mathrm{pH} 4.0$ and 4.5 and only $45 \mathrm{~g} \mathrm{~L}^{-1}$ at $\mathrm{pH} 3.5$. Furthermore, the ethanol production at $38^{\circ} \mathrm{C}$ was nearly $25 \mathrm{~g} \mathrm{~L}^{-1}$ at $\mathrm{pH} 4.0$ and 4.5 and $20 \mathrm{~g} \mathrm{~L}^{-1}$ at $\mathrm{pH} 3.5$. These data confirm that $S$. cerevisiae performed best at $28{ }^{\circ} \mathrm{C}$ (Table 1 ), particularly regarding its productivity, which was approximately $1 \mathrm{~g}$ of ethanol per $\mathrm{L}$ and per $\mathrm{h}$. The fermentation results for T. delbrueckii are shown in Figure 3. This yeast species developed poorly under the tested growth conditions compared to $S$. cerevisiae. Torulaspora delbrueckii had a very slow fermentation at 18
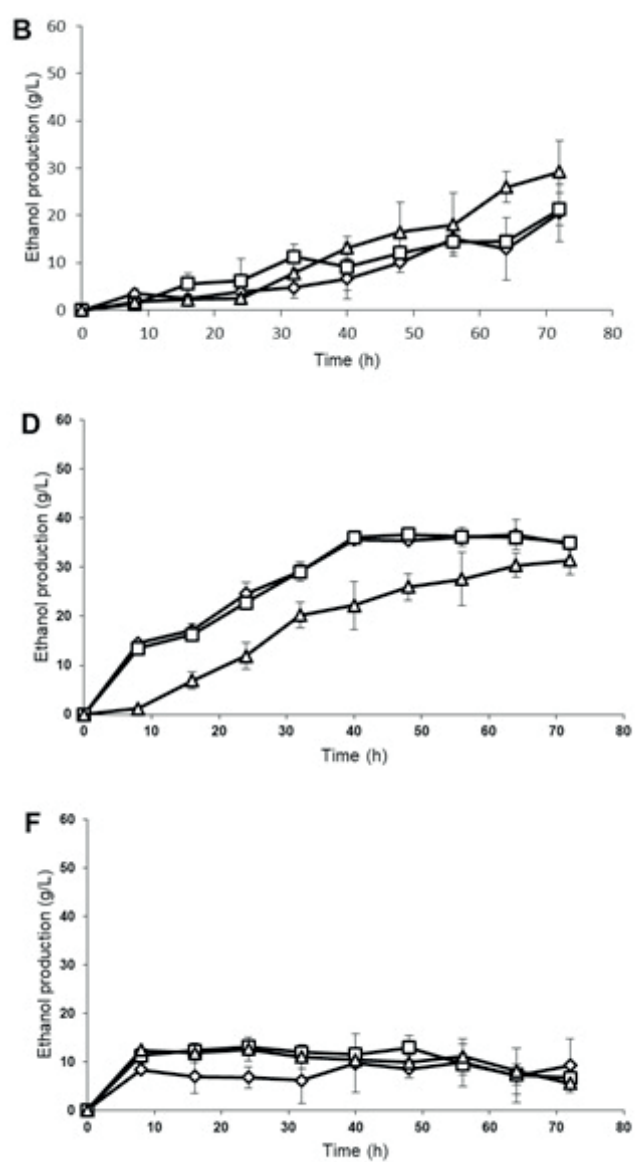

Figure 2. Fermentation kinetics of Saccharomyces cerevisiae ITD-00185 in agave juice at different temperatures and $\mathrm{pH}$ values. Sugar consumption (A, C, E) and ethanol production (B, D, F). Incubation temperature of $18{ }^{\circ} \mathrm{C}(\mathrm{A}, \mathrm{B}), 28{ }^{\circ} \mathrm{C}(\mathrm{C}$, D) and $38^{\circ} \mathrm{C}(\mathrm{E}, \mathrm{F})$. pH values of $3.5(\diamond), 4.0(\square)$ and $4.5(\triangle)$. 
${ }^{\circ} \mathrm{C}$, particularly at $\mathrm{pH} 3.5$ (Fig. 3A and 3B). Its sugar consumption of approximately $70 \mathrm{~g} \mathrm{~L}^{-1}$ was observed after $72 \mathrm{~h}$ incubation period at $\mathrm{pH} 4.0$ and 4.5; however, its consumption was $43 \mathrm{~g} \mathrm{~L}^{-1}$ at $\mathrm{pH}$ 3.5. T. delbrueckii's ethanol production ranged from 21 ( $\mathrm{pH} 3.5$ ) to $29 \mathrm{~g} \mathrm{~L}^{-1}$ ( $\mathrm{pH} 4.5$ ). Fermentation at $28^{\circ} \mathrm{C}$ (Fig. 3C and 3D) was faster than at $18{ }^{\circ} \mathrm{C}$ in all cases. Comparison of the different fermentation levels at $28{ }^{\circ} \mathrm{C}$ showed that the $T$. delbrueckii cultures incubated at $\mathrm{pH} 3.5$ and 4.0 showed similar behaviors; however, the slowest fermentation occurred at $\mathrm{pH} 4.5$, in contrast to the behavior observed at $18{ }^{\circ} \mathrm{C}$, where the slowest recorded fermentation occurred at $\mathrm{pH} 3.5$. Importantly, at $28^{\circ} \mathrm{C}, T$. delbrueckii consumed sugars and produced ethanol in amounts similar to $S$. cerevisiae; however, $T$. delbrueckii took $14 \mathrm{~h}$ longer to reach these levels. T. delbrueckii was practically unable to ferment sugars at 38 ${ }^{\circ} \mathrm{C}$ (Fig. 3E and 3F), independent of the $\mathrm{pH}$ level present. In all cases, its sugar consumption and ethanol production (approximately $20 \mathrm{~g} \mathrm{~L}^{-1}$ and $10 \mathrm{~g} \mathrm{~L}^{-1}$, respectively) were observed during the first $8 \mathrm{~h}$. After this time, the fermentation process did not continue. Table 1 shows that, similar to $S$. cerevisiae, T. delbrueckii showed its best results at $28{ }^{\circ} \mathrm{C}$.

The fermentation kinetics using the mixed culture are shown in Figure 4. It is important to note that
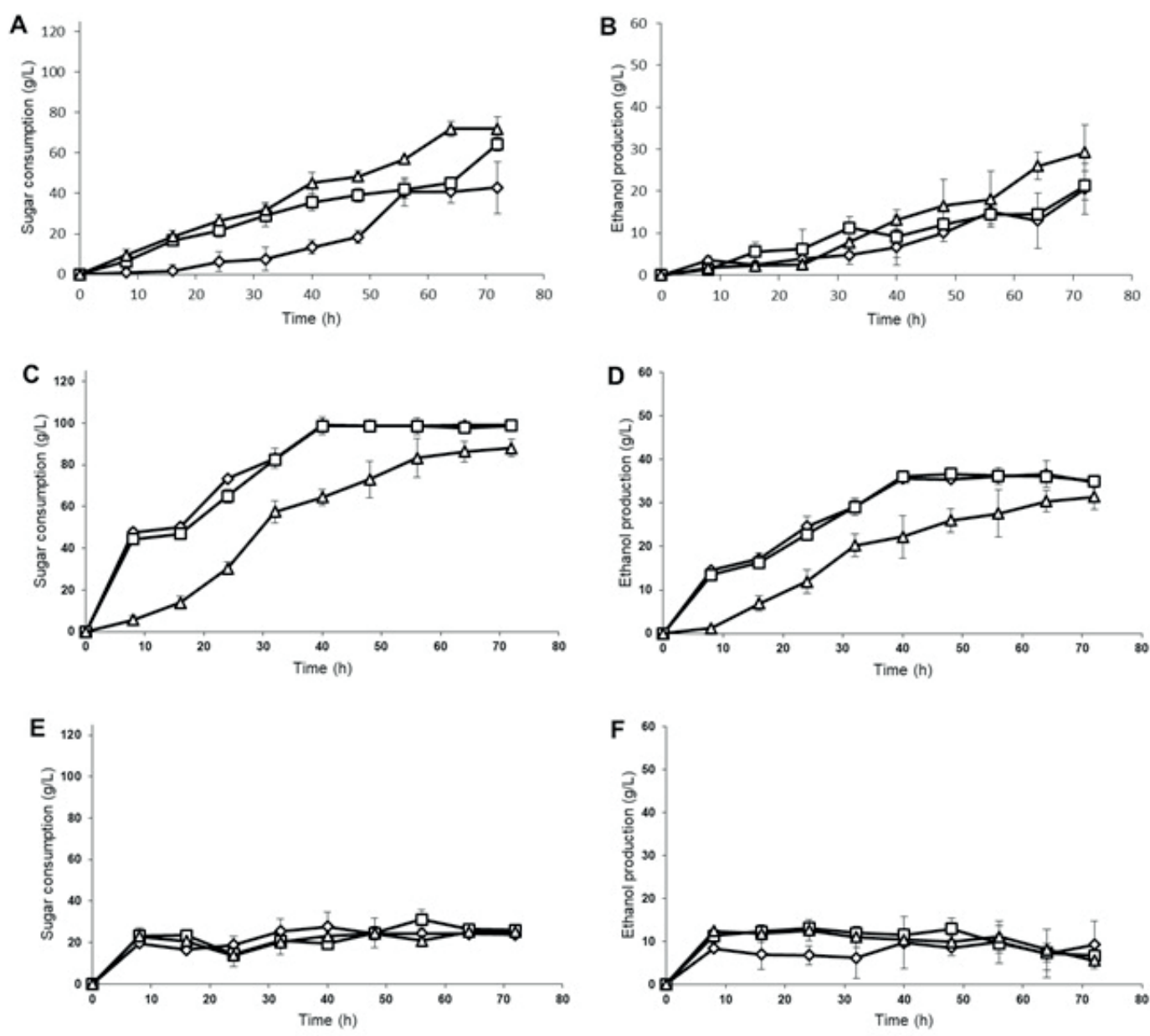

Figure 3. Fermentation kinetics of Torulaspora delbrueckii ITD-00014a in Agave duranguensis juice at different temperatures and $\mathrm{pH}$ values. Sugar consumption (A, C, E) and ethanol production (B, D, F). Incubation temperature of 18 ${ }^{\circ} \mathrm{C}(\mathrm{A}, \mathrm{B}), 28^{\circ} \mathrm{C}(\mathrm{C}, \mathrm{D})$ and $38^{\circ} \mathrm{C}(\mathrm{E}, \mathrm{F})$. $\mathrm{pH}$ values of $3.5(\diamond), 4.0(\square)$ and $4.5(\triangle)$. 
Table 1. Temperature and $\mathrm{pH}$ effect on the yield and productivity of ethanol using different inocula.

\begin{tabular}{|c|c|c|c|c|}
\hline Temperature & Temperature & $\mathrm{pH}$ & $\begin{array}{c}Y_{P / S} \\
\left(\mathrm{~g} \mathrm{EtOH}[\mathrm{g} \text { Sugar }]^{-1}\right)\end{array}$ & $\begin{array}{l}\text { Productivity } \\
\left(\mathrm{g} \mathrm{EtOH} \mathrm{L}^{-1} \mathrm{~h}^{-1}\right)\end{array}$ \\
\hline \multirow[t]{9}{*}{ Saccharomyces cerevisiae } & \multirow[t]{3}{*}{$18^{\circ} \mathrm{C}$} & 3.5 & $0.419 \pm 0.028$ & $0.579 \pm 0.060$ \\
\hline & & 4.0 & $0.330 \pm 0.009$ & $0.701 \pm 0.076$ \\
\hline & & 4.5 & $0.362 \pm 0.011$ & $0.825 \pm 0.070$ \\
\hline & \multirow[t]{3}{*}{$28^{\circ} \mathrm{C}$} & 3.5 & $0.387 \pm 0.010$ & $0.958 \pm 0.072$ \\
\hline & & 4.0 & $0.407 \pm 0.012$ & $0.984 \pm 0.083$ \\
\hline & & 4.5 & $0.404 \pm 0.016$ & $1.005 \pm 0.040$ \\
\hline & \multirow[t]{3}{*}{$38^{\circ} \mathrm{C}$} & 3.5 & $0.450 \pm 0.034$ & $0.517 \pm 0.068$ \\
\hline & & 4.0 & $0.390 \pm 0.009$ & $0.651 \pm 0.080$ \\
\hline & & 4.5 & $0.357 \pm 0.002$ & $0.627 \pm 0.095$ \\
\hline \multirow[t]{9}{*}{ Torulaspora delbrueckii } & \multirow[t]{3}{*}{$18^{\circ} \mathrm{C}$} & 3.5 & $0.429 \pm 0.104$ & $0.167 \pm 0.042$ \\
\hline & & 4.0 & $0.327 \pm 0.015$ & $0.227 \pm 0.028$ \\
\hline & & 4.5 & $0.357 \pm 0.038$ & $0.329 \pm 0.043$ \\
\hline & \multirow[t]{3}{*}{$28^{\circ} \mathrm{C}$} & 3.5 & $0.362 \pm .009$ & $0.892 \pm 0.109$ \\
\hline & & 4.0 & $0.366 \pm 0.009$ & $0.903 \pm 0.120$ \\
\hline & & 4.5 & $0.349 \pm 0.012$ & $0.555 \pm 0.043$ \\
\hline & \multirow[t]{3}{*}{$38^{\circ} \mathrm{C}$} & 3.5 & $0.360 \pm 0.047$ & $0.243 \pm 0.033$ \\
\hline & & 4.0 & $0.342 \pm 0.123$ & $0.289 \pm 0.078$ \\
\hline & & 4.5 & $0.371 \pm 0.131$ & $0.259 \pm 0.061$ \\
\hline \multirow{9}{*}{$\begin{array}{l}\text { Mixed culture }(75 \% S \text {. } \\
\text { cerevisiae, } 25 \% \text { T. delbrueckii) }\end{array}$} & \multirow[t]{3}{*}{$18^{\circ} \mathrm{C}$} & 3.5 & $0.375 \pm 0.048$ & $0.257 \pm 0.175$ \\
\hline & & 4.0 & $0.364 \pm 0.030$ & $0.805 \pm 0.119$ \\
\hline & & 4.5 & $0.362 \pm 0.005$ & $1.065 \pm 0.110$ \\
\hline & \multirow[t]{4}{*}{$28^{\circ} \mathrm{C}$} & 3.5 & $0.465 \pm 0.008$ & $1.249 \pm 0.154$ \\
\hline & & 4.0 & $0.447 \pm 0.005$ & $1.297 \pm 0.152$ \\
\hline & & 4.5 & $0.433 \pm 0.009$ & $1.320 \pm 0.152$ \\
\hline & & 3.5 & $0.444 \pm 0.027$ & $0.629 \pm 0.092$ \\
\hline & \multirow[t]{2}{*}{$38^{\circ} \mathrm{C}$} & 4.0 & $0.481 \pm 0.041$ & $0.542 \pm 0.078$ \\
\hline & & 4.5 & $0.353 \pm 0.013$ & $0.689 \pm 0.081$ \\
\hline
\end{tabular}

the combined concentration in the mixed culture was $1 \times 10^{7}$ cells $\mathrm{mL}^{-1}$, which was equal to the fermentations performed in monoculture. Figures $4 \mathrm{~A}$ and $4 \mathrm{~B}$ show that, at $18{ }^{\circ} \mathrm{C}$, the $\mathrm{pH}$ had a strong effect on the performance of the coculture of $S$. cerevisiae and T. delbrueckii. At $\mathrm{pH} 4.5$, the fermentation profile (sugar consumption and ethanol production) was better than the profile observed for the $S$. cerevisiae monoculture, which suggests a synergistic effect between the two yeast species. Nevertheless, the fermentation profile at $\mathrm{pH} 3.5$ was seriously affected, which may be attributed to an antagonistic effect. In all of the mixed culture cases tested, the most significant positive effect recorded was at $28^{\circ} \mathrm{C}$, especially at $\mathrm{pH} 4.0$ and 4.5. This finding was demonstrated by higher levels of sugar consumption and ethanol production $(\sim 20 \%, p<0.05)$ compared to the production levels of the $S$. cerevisiae monoculture. Similarly, Lu et al. (2017) reported that the $\mathrm{pH}$ had a more significant effect on ethanol production than did temperature during alcoholic fermentation for wine production. Figures $4 \mathrm{E}$ and $4 \mathrm{~F}$ show that $38^{\circ} \mathrm{C}$ is an adverse temperature for the development of the tested yeasts. Table 1 shows that in the mixed cultures, a very positive effect was observed at 18 ${ }^{\circ} \mathrm{C}$ and $\mathrm{pH} 4.5$ because the productivity increased by approximately $30 \%(p<0.05)$ compared with the fermentation of the $S$. cerevisiae monoculture under the same conditions. A positive effect was observed at $\mathrm{pH} 4.0$, showing a $15 \%(p<0.05)$ increase in productivity, whereas the effect at $\mathrm{pH}$ 

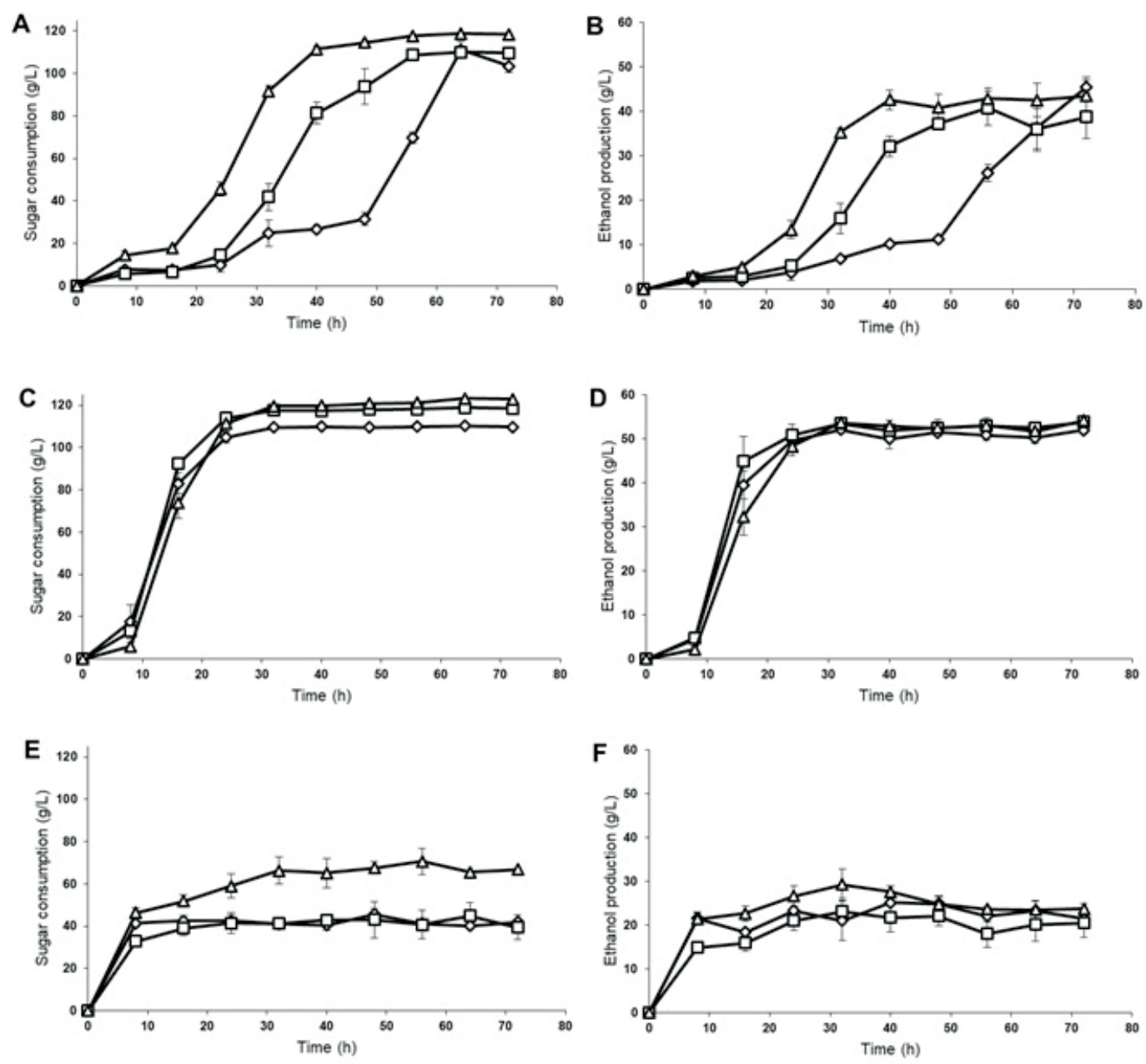

Figure 4. Fermentation kinetics of mixed cultures of Saccharomyces cerevisiae ITD-00185 and Torulaspora delbrueckii ITD-00014a in Agave duranguensis juice at different temperatures and $\mathrm{pH}$ values. Sugar consumption (A, C, E) and ethanol production $(\mathrm{B}, \mathrm{D}, \mathrm{F})$. Incubation temperature of $18{ }^{\circ} \mathrm{C}(\mathrm{A}, \mathrm{B}), 28^{\circ} \mathrm{C}(\mathrm{C}, \mathrm{D})$ and $38^{\circ} \mathrm{C}(\mathrm{E}, \mathrm{F})$. pH values of $3.5(\diamond)$, $4.0(\square)$ and $4.5(\triangle)$.

3.5 was strongly negative, with a productivity decrease of $56 \%(p<0.05)$. The positive effect of the coculture was very evident at $28^{\circ} \mathrm{C}$ because the productivity increased an average of $31 \%$ $(p<0.05)$ in all three cases; whereas at $38{ }^{\circ} \mathrm{C}$, pH 3.5 and 4.5 were not substantially affected in comparison with the $S$. cerevisiae monoculture. A negative effect on the productivity of the coculture was observed at $38^{\circ} \mathrm{C}$ and $\mathrm{pH} 4.0$ $(-17 \%, p<0.05)$.

Ciani et al. (2016) noted the complexity of the interaction between non-Saccharomyces and Saccharomyces yeast strains, which was influenced by many abiotic (temperature, $\mathrm{pH}$, nutrients) and biotic (cell-to-cell contact, proteinaceous antimicrobial compounds) factors. They also noted that the physiological and biochemical basis for these interactions were still unclear, though they suggested a multifactorial approach using omics methodologies to elucidate the yeast species interactions. Our research group previously postulated a synergistic interaction between $S$. cerevisiae ITD-00185 and T. delbrueckii ITD00014a (Nuñez-Guerrero et al., 2016). Nevertheless, the results presented in this work suggest that a more complex interaction occurs between the two yeast species because both positive (syn- 
ergistic) and negative (antagonistic) interactions were recorded depending on the environmental conditions.

The main conclusions are the following. The inoculum concentration is an important parameter for the fermentation performance of the tested yeast species. Saccharomyces cerevisiae ITD-00185 showed high performance levels at all of the inoculum concentrations assayed; however, T. delbrueckii ITD-00014a required a high inoculum concentration $\left(\geq 1 \times 10^{7}\right.$ cells $\left.\mathrm{mL}^{-1}\right)$ to perform at fermentation levels similar to $S$. cerevisiae. Low temperatures $\left(18{ }^{\circ} \mathrm{C}\right)$ slowed fermentation; however, the highest temperature $\left(38^{\circ} \mathrm{C}\right)$ was adverse for the development of these yeast species, especially for T. delbrueckii. The best temperature for the yeast strains was $28{ }^{\circ} \mathrm{C}$ at which they underwent vigorous fermentation. Finally, we conclude that the coculture of the two yeast species produced results that are not simply the sum of each separately cultured yeast species' performance. Therefore, we postulate that a complex interaction exists between the two yeast species and that this interaction may be synergistic or antagonistic as the environmental conditions change. These interactions will be further elucidated in future experiments.

\section{Resumen}

M.E. Nuñez-Guerrero, E. Salazar-Vázquez, J.B. Páez-Lerma, R. Rodríguez-Herrera, y N.O. Soto-Cruz. 2019. Caracterización fisiológica de dos levaduras nativas en cultivo puro y mixto usando fermentaciones de jugo de agave. Cien. Inv. Agr. 46(1): 1-11. Las levaduras se someten a diversas condiciones ambientales durante la fermentación alcohólica de jugo de agave, causando diferentes comportamientos cinéticos. Se utilizó jugo de agave como medio de cultivo para evaluar el comportamiento cinético de Saccharomyces cerevisiae ITD-00185 y Torulaspora delbrueckii ITD-00014a, en cultivos puros y mezclados, en diferentes condiciones de tamaño de inóculo $\left(1 \times 105,1 \times 106,1 \times 107\right.$ y $1 \times 108$ células $\left.\mathrm{ml}^{-1}\right)$ y combinaciones de $\mathrm{pH}(3.5$, 4.0 y 4.5$)$ y temperatura $\left(18{ }^{\circ} \mathrm{C}, 28^{\circ} \mathrm{C}\right.$ y $\left.38^{\circ} \mathrm{C}\right)$. Saccharomyces cerevisiae mostró alta capacidad fermentativa en todas las concentraciones de inóculo. Torulaspora delbrueckii requirió alta concentración de inóculo $\left(\geq 1 \times 107\right.$ células $\left.\mathrm{mL}^{-1}\right)$ para fermentar como $S$. cerevisiae. A $18{ }^{\circ} \mathrm{C}$ se retardó la fermentación, mientras que a $38^{\circ} \mathrm{C}$ se afectó negativamente al desarrollo de las levaduras, especialmente $T$. delbrueckii. La fermentación fue vigorosa para ambas levaduras a $28^{\circ} \mathrm{C}$. El pH tuvo un fuerte efecto sobre el rendimiento del co-cultivo, sugiriendo un efecto sinérgico a $\mathrm{pH} 4.5$ y efecto antagónico a $\mathrm{pH}$ 3.5. Para cultivo mixto se observó un efecto positivo a $28{ }^{\circ} \mathrm{C}$, especialmente a $\mathrm{pH} 4.0$ y 4.5 , demostrando mejor consumo de azúcar y producción de etanol $(\sim 20 \%, \mathrm{p}<0,05)$ comparado con el monocultivo de $S$. cerevisiae. Los resultados globales permiten postular una interacción compleja entre las dos levaduras, que puede ser sinérgica o antagónica, según las condiciones ambientales.

Palabras clave: Co-cultivo, concentración de inoculo, $\mathrm{pH}$, temperatura.

\section{References}

Agreement between the European Community and the United Mexican States on the mutual recognition and protection of designations for spirit drinks. 1997. Off. J. Eur. Community. L152:16-26.
Alexandre, H., I. Rousseaux, and C. Charpentier. 1994a. Ethanol adaptation mechanisms in Saccharomyces cerevisiae. Biotechnol. App. Biochem. 20:173-183.

Alexandre, H., I. Rousseaux, and C. Charpentier. 1994b. Relationship between ethanol toler- 
ance, lipid composition and plasma membrane fluidity in Saccharomyces cerevisiae and Kloeckera apiculata. FEMS Microbiol. Lett. 124:17-22.

Caridi, A. 2003. Effect of protectans of the fermentation performance of wine yeasts subjected to osmotic stress. J. Food Technol. 41:141-148.

Ciani, M., A. Capece, F. Comitini, L. Canonico, G. Siesto, and P. Romano. 2016. Yeast interactions in inoculated wine fermentation. Front. Microbiol. 7:555.

De los Ríos-Deras, G.C., O.M. Rutiaga-Quiñones, J. López-Miranda, J.B. Páez-Lerma, M. López, and N.O. Soto-Cruz. 2015. Improving Agave duranguensis must for enhanced fermentation. $\mathrm{C} / \mathrm{N}$ ratio effects on mezcal composition and sensory properties. Rev. Mex. Ing. Quím. 14:363-371.

Escalante-Minakata, P., H. Blaschek, A. Barba-de la Rosa, L. Santos, and A. De León-Rodríguez. 2008. Identification of yeast and bacteria involved in the mescal fermentation of Agave salmiana. Lett. Appl. Microbiol. 46:626-630.

Esteve-Zarzoso, B., P. Manzanares, D. Ramon, and A. Querol. 1998. The role of non-Saccharomyces yeasts in industrial winemarking. Int. Microbiol. 1:143-148.

Hohman, S., and W.H. Mayer. 2003. Yeast stress responses. Springer-Verlag: Berlin Heidelberg.

Hohmann, S. 2002. Osmotic stress signaling and osmoadaptation in yeasts. Microbiol. Mol. Biol. Rev. 66:300-372.

Lappe-Oliveras, P., R. Moreno, J. Arrizón, T. Herrera, A. García, and A. Gschaedler. 2008. Yeasts associated with the production of Mexican alcoholic nondistilled and distilled Agave beverages. FEMS Yeast Res. 8:1037-1052.

Lu, Y., M.K.W. Voon, D. Huang, P.R. Lee, and S.Q. Liu. 2017 Combined effects of fermentation temperature and $\mathrm{pH}$ on kinetic changes of chemical constituents of durian wine fermented with Saccharomyces cerevisiae. Appl. Microbiol. Biotechnol. 101:3005.
Mauricio, J.C., and J.M. Salmon. 1992. Apparent loss of sugar transport activity in Saccharomyces cerevisiae may mainly account for maximum ethanol production during alcoholic fermentation. Biotechnol. Lett. 14:577-582.

Narváez-Zapata, J.A., R.A. Rojas-Herrera, I.C. Rodríguez-Luna, and C.P. Larralde-Corona. 2010. Culture-independent analysis of lactic acid bacteria diversity associated with mezcal fermentation. Curr. Microbiol. 61:444-450.

Nishino, H., S. Miyazaki, and K. Tohjo. 1985. Effect of osmotic pressure on the growth rate and fermentation activity of wine yeasts. Am. J. Enol. Vit. 36:170-174.

Nissen, P., and N. Arneborg. 2003. Characterization of early deaths of non-Saccharomyces yeast in mixed cultures with Saccharomyces cerevisiae. Arch. Microbiol. 180:257-263.

Nuñez-Guerrero, M.E., J.B. Páez-Lerma, O.M. Rutiaga-Quiñones, S.M. González-Herrera, and N.O. Soto-Cruz. 2016. Performance of mixtures of Saccharomyces and non-Saccharomyces native yeasts during alcoholic fermentation of Agave duranguensis juice. Food Microbiol. 54:91-97.

Páez-Lerma, J.B., A. Arias-García, O.M. RutiagaQuiñones, E. Barrio, and N.O. Soto-Cruz. 2013. Yeasts isolated from the alcoholic fermentation of Agave duranguensis during mezcal production. Food Biotechnol. 27:342-356.

Pampulha, M.E., and M.C. Loureiro-Dias. 1990. Activity of glycolytic enzymes of Saccharomyces cerevisiae in the presence of acetic acid. Appl. Microbiol. Biotechnol. 34:375-380.

Pretorius, I., M. Toit, and P. Rensburg. 2003. Designer yeast for the fermentation industry of the 21 st century. Food Technol. Biotechnol. 41:3-10.

Secretaría de Comercio y Fomento Industrial. 1994. Norma Oficial Mexicana: NOM-070.SCFI-Bebidas alcohólicas. Mezcal- especificaciones.

Soto-García, E., M. Rutiaga-Quiñones, J. LópezMiranda, L. Montoya-Ayón, and O. Soto-Cruz. 
2009. Effect of fermentation temperature and must processing on process productivity and product quality in mescal fermentation. Food Control. 20:307-309.

Taillandier, P., Q.P. Lai, A. Julien-Ortiz, and C. Brandam. 2014. Interactions between Torulaspora delbrueckii and Saccharomyces cerevisiae in wine fermentation: influence of inoculation and nitrogen content. World J. Microbiol. Biotechnol. 30:1959-1967.

Viegas, C.A., M.F. Rosa, I. SA-Correia, and J.M. Novais. 1989. Inhibition of yeast growth by octanoic and decanoic acids produced during ethanolic fermentation. Appl. Environ. Microbiol. 55:21-28.

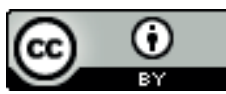

This work is licensed under a Creative Commons Attribution 4.0 International License. 